\title{
Editorial
}

\section{Working at Home}

One of the fastest growing sectors in developed industrial economies, especially in the U.S.A., is work at home. Work at home relates to selfemployment, part-time self-employment, work after regular office hours, work instead of regular office hours, self-service and do-it-yourselfing, typically relying on home office, telecommuting, neighborhood networks, personal computers, modem, fax, multiple and cellular telephone lines and similar technologies.

Donald and Nastia Vickery in Kailua, Oahu, are typical protagonists of this new business, lifestyle and cultural alternative. Their backroom home office includes a stable of Apple computes, faxes, telephones plus a lot of that old independent, selfreliant, all-American attitude. They run their vending-machine business from home, rent out their bed \& breakfast apartment (previously garage), work at four in the morning, at ten at night or not at all on some days. They are free. Thanks to new technologies, they have regained a fuller charge of their company-regimented lives.

Donald and Nastia have themselves, and in spite of aggressive governmental obstacles, generated two high-pay jobs plus a number of job opportunities for local homekeepers, caretakers and suppliers. Their job-generating ability, considering the same potential of hundreds of millions fellow Americans, is unparalleled, nothing short of awesome.

Work at home is now the most potent jobgenerating sector, moving the self-reliant population towards most productive and efficient selfservice activities, reducing the pressures on energy, ecology, humans stress, traffic congestion and the cost-intensive physical commuting we have inherit-

IOS Press

Human Systems Management 12 (1993) 81-83 ed from the turn of the century. Clearly, individual or corporate telecommuniting presents a powerful alternative to the medieval "railroads, highways and bridges".

One should stop and ponder how can a modern politician advocate both electronic superhighways and medieval "roads and bridges", all at the same time and at the end of the twentieth century? Modern production is primarily based on processing of information, not on hauling of goods, humans and machinery over large distances. One can more effectively "haul the information", to produce goods and provide services locally. Information and knowledge travel effortlessly through electronic superhighways, through telecommunications networks.

Citizens and employees working at home are in control of their time, can take care of their children, can invest in home-technologies; they do not have to pay excessively for gasoline, insurance, kindergartens and waste most of their precious off-work hours travelling on those "roads, rails and bridges".

The U.S.A. is already waking up to the challenge of the twenty-first century, although its own government is far from it. The U.S. governmental is still "building bridges" and in fact fighting the work at home, outlawing many home offices, penalizing multiple phone lines, taxing self-employment, self-help, self-reliance or any other expressions of employee empowerment, autonomy and self-management. Such a misplaced attitude is the sad inheritance of the hierarchical 1960s.

Yet, in spite of the government, there were already about 40 million (!) Americans working at home in 1992. This is to be compared with only some 25 million in 1988. From these 40 million home workers, there are 12.1 million selfemployed, 11.7 million part-time self-employed, 
8.6 million working at home after regular office hours, and 6.6 million working at home instead of regular office hours. All such spontaneously and non-governmentally created high-tech, well-paid jobs still receive no meaningful governmental encouragement, tax-breaks, investment or write-off supports. The government is still proposing to build bridges and swimming pools, yet people are striving to become autonomous, empowered and working at home.

The Bank of America is cutting thousands of full-time teller positions and offering employees part-time jobs. The technology of ATM machines increases customer self-service (cheaper, more efficient) and reduces traditional bank services (more expensive, time consuming). Self-service gas stations, customer-operated optical scanners in supermarkets, do-it-yourself pregnancy tests and customer-friendly maintenance, repair and assembly/production technologies - all are part of the same trend and self-service phenomenon.

The disappearance of traditional jobs is due to the ever increasing productivity of the United States economy. If we take value-added per hour worked in the U.S.A. as 100, then in all business France and Germany are at about 80, Britain at 70 and Japan at 55; in manufacturing only Germany, Japan and France are at about 80, Britain at 60 .

The productivity differences in services (airlines, banking, restaurants, retailing and telecommunications) are especially telling. The productivity of American shop workers is almost twice that of those in Japan. In airlines, the productivity of American firms is a third higher than that of European ones.

The most powerful reason for productivity differences in services is not only due to high technology, but mainly due to openness to competition, good labor practices and most flexible labor markets.

The ability and willingness of Americans, combined with the economic necessity of working at home, fully or partially, is the main job-generating engine - not the "new-dealy" governmentally sponsored summer jobs and other "bridgebuilding" make-believe pseudojobs. This is not what America, or the promise of America, can be all about.
High technologies: E-mail, computer-teleconferencing, real-time-teleconferencing, and video-teleconferencing are all helping to create electronic networks necessary for self-help and work-at-home business-styles. But the distributed and asynchronous communication systems are the key: they allow global interaction to take place at different places and at different times - creating time/space collaborative systems of unprecedented productivity. Physically "going-to-work-with-a-lunch-box" type of interaction is becoming rapidly outmoded: unless there is actual physical transformation taking place in situ, all necessary information-processing is mostly location-independent.

Understanding and interacting, transmitting and enhancing knowledge, is often better than just being there. Should employees be expected to - at the dawn of the twenty-first century - commute to and from their work stations and computer-equipped offices, spend countless wasted hours on airplanes and in hotel rooms, make very bad use of time which is increasingly becoming a very limited, if not precious, resource? The face-to-face meeting, while still quite useful in procreation, is not all that effective in business idea-creation.

Are not "virtual meetings" better? Video-teleconferencing captures all the expressions, sights and sounds: shouldn't it become an individual working-desk activity, like picking up a telephone or sending a fax? Voice, video and data can now be compressed and communicated through opticalfiber channels.

Electronic meetings must be better than face-toface meetings, not only in terms of cost, but in terms of productivity, multiple-participants management and coordination, as well as all the telepresence (including physical manipulation and production) advantages of the global economy. The first generation of mass-market, affordable telepresence gear will enter the markets in 1994.

Because knowledge is a purposeful and consensual coordination of action, so-called coordination sciences are going to support knowledge networks of collaborative writing, information processing and production interaction. Such knowledge networks are shareable across global networks and readable, browsable and searchable by any individual computer. 
Group decision support systems (GDSS) are most useful for self-help and self-service interactions: decision structuring, idea generation, voting, ranking, etc. Even the long-neglected project-management techniques, like CPM and PERT, are making their comeback via GDSS (VisionQuest, Idea Organisation, TeamGraphics, etc.).

But key people are still very slow: they are only now learning to use voice and electronic mail. Some are afraid of any groupware because it is so quick and so mercilessly democratic. Managers are still accustomed to give commands and process tons of paperwork in a centrally-planned command system. They do not know how to operate in an intracompany free-market democracy.

The governments, unfortunately, are still the slowest and most resistant laggards in understanding new technologies, new job-creation imperatives and the new culture: they still do not grasp that we do not live in the sixties and that the employee's work location is becoming rapidly irrelevant.

It is difficult to imagine that after the year 2000 any company could successfully and globally compete while still clinging to the 1930s-mode of having thousands of staff-employees packed all in one physical location.

Milan ZELENY

Graduate School of Business

Fordham University at Lincoln Center

New York, NY 10023

U.S.A. 